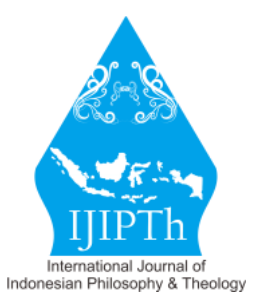

\title{
Interdisciplinary Perspectives and Approaches in Theologizing in Asia
}

\author{
Daniel Franklin E. Pilario \\ St. Vincent School of Theology, Adamson University, Philippines \\ Email: danielfranklinpilario@yahoo.com
}

\begin{abstract}
Abtsract: This article attempts to answer the question how interdisciplinary is theology in the Asian context? It tackles the issue in three distinct parts: (1) the notion of interdisciplinarity; (2) the relationship between theology and other disciplines; and (3) the principles and practices of interdisciplinary theologizing in Asia. This article uses the literature study method, using various references and literature. First, interdisciplinarity feeds on the concept of scientific disciplinarily. Though "disciplines" as domains of knowledge exist from the Greeks to the scholastics, disciplinary specialization is a modern creation. The subsequent scientific compartmentalization longed for a synthesis, thus, leading to the varied ways of relating among scientific disciplines expressed in terms like interdisciplinarity, multidisciplinary and transdisciplinary. The second part of the article maps how theology has dealt with its "other" throughout history. The third section argues for the dialogical character of both Asian cultures and Asian Christianity. Finding themselves in a land characterized by plural philosophies and religions, it cannot exist but be in dialogue with others. In the Asian continent, the serenity of the lotus meets the defiance of the cross bringing out a theology that expresses both harmony and prophecy, equilibrium and transformation. The article ends by showing methodological principles, theological methods, present practitioners and emerging questions generated by this complex interdisciplinary interaction on the Asian soil.
\end{abstract}

Keywords: multidisciplinary, transdisciplinary, Asian philosophies, Asian religions

\begin{abstract}
Abstrak: Artikel ini berusaha menjawab pertanyaan bagaimana teologi interdisipliner dijalankan dalam konteks Asia? Ada tiga isu yang digarap: (1) makna interdisiplinaritas; (2) keterpautan antara teologi dan disiplin lain; (3) prinsip dan praksis berteologi interdisipliner di Asia. Artikel ini menggunakan metode studi pustaka, dengan mengunakan berbagai referensi dan literatur. Bagian pertama menggali interdisiplinaritas dalam ilmu-ilmu. Keanekaragaman ilmu-ilmu disimak mulai dari periode filsafat Yunani hingga Skolastik. Ilmu-ilmu modern mendistingsi "keilmiahan" dalam interdisiplinaritas, multidisiplinaritas, dan transdisiplinaritas. Bagian kedua membahas bagaimana teologi mengurus "yang lain" dalam sejarah. Bagian ketiga berargumentasi terkait dengan karakter dialogal dari keduanya, yaitu baik kultur Asia maupun Kekristenan Asia. Karena mendarat di tanah yang bercirikan filsafat dan kebudayaan yang beraneka macam, Kekristenan Asia tidak mungkin melepaskan diri dari dialog dengan yang lain. Di benua Asia, kedamaian lotus berjumpa dengan penebusan salib yang produknya mengukir harmoni dan kritisi, keseimbangan dan transformasi. Artikel berakhir dengan prinsip-prinsip metodologis, metode teologis dari para praktisi saat ini, dan pertanyaan-pertanyaan penting yang muncul dari interaksi interdisipliner yang kompleks di tanah Asia.
\end{abstract}

Kata kunci: multidisiplin, transdisiplin, filosofi Asia, agama-agama Asia

\section{Introduction}

A Nobel Prize winner, Herbert Simon (1992, p. 269), writes: "Disciplines, like nations, are a necessary evil that enables human beings of bounded rationality to simplify the structure of their goals. But parochialism is everywhere, and the world surely needs international and interdisciplinary travelers who will carry new knowledge from one cave to another." This paper aims to explore on the state of interdisciplinarity and Christian theology in the Asian context. I will do this in four steps: first, I will discuss the contemporary developments on this new field called interdisciplinarity; second, I will attempt to a cursory survey of the ambivalent relationship between Christian theology and 
interdisciplinary; and third, I will explore some methodological principles, models and related to theological interdisciplinarity in the Asian context.

To understand interdisciplinary and its application to theology, we need to start with the concept of "discipline" as a domain of knowledge. Different knowledge domains existed from ancient times. Plato's Academy taught geometry, sciences, law and politics. Aristotle's Lyceum distinguished different subjects: biology and botany, music and mathematics, physics and metaphysics, logic and law, politics and rhetoric, and so on. The Carolingian cathedral schools have trivium (grammar, logic and rhetoric) and quadrivium (music, geometry, arithmetic and astronomy). Medieval universities have four faculties - theology, arts, medicine and law. But these ancient and medieval knowledge production processes aimed not so much at rigid specialization but at totality, integration and synthesis. The medieval university, for instance, was in itself a "little city" whose aim is to foster a twofold "universitas" or community, i.e., universitas magistrorum et scholarium (community of teachers and students) and universitas scientiarum (community of disciplines of knowledge) (Klein, 1990, pp. 1922). It is space to earn comprehensive education toward the formation of homo universalis (universal man).

But by the middle of the $18^{\text {th }}$ century, 'universalistic' thinking had already begun to fade from the intellectual landscape. New social, economic and cultural developments like the industrial revolution, technological progress, the evolution of modern sciences, necessitates specialized knowledges. That is why we can say that "disciplines" (i.e., disciplinary specialization) are a modern creation. On the one hand, it is a sign of society positively adapting itself to its environment that has become more complex than ever. The more complex society becomes, the more it needs specialization to cope up with its complexity. A contemporary sociologist, Luhmann (1977), argues that a system can only survive in a highly complex world if it also replicates within its own organization the complexity of its environs. In the process, there is more potential for it to survive and evolve. This is true for all modern social systems (politics, culture, economy, religion, etc.) but also for systems of knowledge (sciences).

On the other hand, the medieval integrated and interlocking systems becomes a thing of the past. The Fathers of Vatican II lamented on this loss and express such longing in a question form: "How can we quickly and progressively harmonize the proliferation of particular branches of study with the necessity of forming a synthesis of them, and of preserving among men the faculties of contemplation and observation which lead to wisdom?" ("Gaudium et Spes," 1965, p. 56). When the Church decidedly and happily opened its windows to the world in Vatican II, it was also feeling nostalgic that the medieval unity of knowledge was gone.

But the new sciences had already emerged earlier - during the latter part of the $19^{\text {th }}$ and the early part of the $20^{\text {th }}$ centuries. The medieval faculties of theology, arts, medicine and law have branched out into new systems of Wissenschaft subsequently differentiated into new disciplinary domains and scientific institutions. Old research programs thus achieved disciplinary status: history in 1884, economics in 1885, political science in 1903, sociology in 1905.

Philosophers assessed the new situation differently. Martin Heidegger, on the one hand, thinks that disciplinary specialization is a necessary consequence, and indeed the positive consequence, of the coming to be of modern science. The delimiting of object-areas, the compartmentalizing of these into special provinces, does not split the sciences off from one another, but rather it first yields a border traffic between them by means of which boundaries are marked out. These areas are the source of a special impetus that produces new formulations of questions that are often decisive (Heidegger, 1977, 
pp. 170-171)

Such questions engendered the discipline's delineated object of inquiry, investigated through its accepted methods, leading to the establishment of its own canons and recognized processes. Heidegger lauds this new development. On the one hand, the existence of disciplinary boundaries is an act of acknowledgement of our limited horizons that occasion the rise of productive questions. On the other hand, disciplinary specialization is also an act of normalization. The separation of knowledge domains has become a new "normal" - a taken for granted everyday reality, considered as natural, one that "goes without saying".

This leads us to an opposite philosophical assessment and the other meaning of "discipline" (i.e., from the seemingly neutral branch of knowledge to a sense of decisive control gained by enforcing a certain kind of order). Against Heidegger, Michel Foucault argues that disciplinary specialization has become an instrument of power. In Discipline and Punish, Foucault argues that modern society establishes a new norm. The "Normal" (e.g., normal schools; ecoles normales) became instruments of coercion and power imposing not only necessary standards, but also limits, hierarchization and surveillance. The marks that once indicated status, privilege and affiliation were increasingly replaced - or at least supplemented - by a whole range of degree of normality indicating membership of a homogenous body but also playing a part in classification, hierarchization and the distribution of rank (Foucault, 1991, p. 184).

In other words, the seeming homogeneity within disciplinary boundaries in different sciences is only a smokescreen of inherent but also tiered and oppressive relations. As example, one can only think of the turfing and the wrangling in highly hierarchized departments in universities and scientific bodies where "experts and professors" replace the place of medieval "reverends and monsignors" as they pontificate from their new modern cathedra. "In a sense, the power of normalization imposes of homogeneity; but it individualizes by making it possible to measure gaps, to determine levels, to fix specialties, and to render differences useful by fitting them one to another. It is easy to understand how the power of the norm functions within a system of formal equality, since within a homogeneity that is the rule, the norm introduces, as a useful imperative and as result of measurement, all the shading of individual references," (Foucault, 1991, p. 184). In this context, the insistence of interdisciplinarity can be construed as a reaction to the modern project of disciplinary specialization. "As a simple fact, interdisciplinarity responds to the failure of expertise to live up to its own hype," (Fuller \& Collier, 2004). We come back to this later. In a recent book entitled The Oxford Handbook of Interdisciplinarity, Julie Thompson Klein (2017) identifies different types of interdisciplinarity in three related terms: multidisciplinary, interdisciplinarity, and transdisciplinary. The first is characterized by the juxtaposition of disciplinary methods and contents; the second, interdisciplinarity, by interaction and collaboration; and the third, transdisciplinary, by transcendence and transgression of fields.

First, multidisciplinary (MD) refers to the use of the methods of other disciplines in order to solve a specific problem within its own domain. It widens its research focus; but it can also be mere juxtaposition or instrumentalist in direction. In theology, for example, Marxist sociology can used in order to analyze the situation (socio-analytic mediation) but it is contextualized and read from a distinctively Christian lens. Its Christian use has been limited to the analytic component not to the whole of its epistemological framework. This is precisely the Vatican's opposition to the use of Marxism in liberation theology (Instruction on Certain Aspects of Theologies of Liberation, 1984). 
The Marxist analytic, it argues, is inseparable from the whole of its epistemology (atheism, class struggle and violence). Yet in the context of interdisciplinary types, liberation theology's use of Marxism is multidisciplinary albeit instrumentalist.

The second type is interdisciplinarity (ID); it refers to the mutual integration and collaboration of disciplines in the level of "organizing concepts, methodology, procedures, epistemology, terminology, data, and organizational research and education," (Klein, 2017, p. 24). For example, we have made an interdisciplinary research on sexually violated women; it was team composed of theologians, social scientists and practitioners (institutions who care for this women).(St. Vincent School of Theology, n.d.) From project planning to interview of key informants' to theological reflection, we have tried our best to involve all perspectives, methods and processes. In an end conference, we structured an encounter among victim-survivors, social scientists, theologians and practitioners with the intention of validating and testing each discipline's findings and conclusions. The result of this interdisciplinary encounter is a sociological and theological reflection on the phenomenon of sexual violence in the Philippine context. Our hope is a more or less holistic view of the phenomenon from different disciplinary perspectives to better respond to it in context. Beyond isolated disciplinary specializations, interdisciplinary seeks integrative knowledge not in a nostalgia of a medieval pre-given order but in a common search in a context of plural, diverse and complex realities.

The third type is transdisciplinary (TD) which can be distinguished from the previous ones through its critical and transgressive dimensions. The move towards interdisciplinarity to transdisciplinary involves transgression - an action at the limits of disciplinary boundaries. "The limit and transgression," Foucault writes, "depend on each other for whatever density of being they possess: a limit could not exist if it were absolutely uncrossable and, reciprocally, transgression would be pointless if it merely crossed a limit composed of illusions and shadows," (Foucault, 1998, p. 73). Even as transdisciplinary presupposes disciplinarily, lives on the presence of disciplines and feeds on them, it also endlessly transgresses them toward new knowledges beyond disciplinary boundaries. While disciplines are characterized by "hierarchical, homogenous and discipline-based work", transdisciplinary is characterized by "complexity, nonlinearity and heterogeneity," (Klein, 2017, p. 30).

\section{Theology and Interdisciplinarity}

Where do we see this present discourse on interdisciplinarity in the theological field? How do we do theology in an interdisciplinary manner? Has theology been always interdisciplinary in nature? Before discussing theological models in Asia, let me outline theology's positions on interdisciplinary relations, that is, its own relationship with other sciences (Brazal and Pilario, 2007).

In the medieval universities, theologies had assumed a central unifying role. Among the four main faculties of the medieval university, theology acquired a place of prominence - the Queen of the sciences. It has occupied the throne from which she uses, classifies, summons, or condemns other disciplinary domains. To her service was its ancilla called philosophia. But theology's relationship and its 'others' (i.e., other sciences) is more complex than that. We can outline this long and convoluted story of such a relationship in five differing models as it is played out through time: (a) theology's refusal of mediation; (b) hegemony of faith; (c) philosophical structuration of the faith; (d) hegemony of scholastic reason; (e) theology in dialogue with its partners. 


\section{A Refusal of Mediation}

The new-found Christian faith must have been an overwhelming experience to new believers so much so that, on its horizons, all human reason fades. This was the experience of the early Fathers of the Church. The total meaning of one's life was found only in the Risen Christ and not in any other human systems of meaning. Tertullian - a Christian educated in the Greek classics - himself exclaimed: "What is there in common between Athens and Jerusalem, between the Academy and he Church? Too bad for those who have embraced a Stoic, a Platonic, or a dialectic Christianity. As for us, we have no need for curiosity after Jesus Christ, or for research after the Gospel," (Congar, 1968, p. 37). As expressed, this view of the 'total sufficiency of Christ' (in effect, also the 'total sufficiency of the Scriptures') which totally rejects any science to mediate the faith shows itself in many shades and forms all throughout the history of Christianity, the most extreme of which is a contemporary AngloAmerican theological fad - radical orthodoxy (Milbank, 1990).

\section{The Hegemony of Faith}

A total rejection of the so-called 'pagan' philosophy is seen by other early Christian thinkers as an impossible position. One could never escape from using the language with which their contemporaries explain their world. There is no other way with which the Councils or individual Christians explain their faith experience but through the same linguistic paradigms. Stoic or Neoplatonic terms and paradigms (e.g., logos, ousia, emanatio) thus found their way into the Christian vocabulary. But such recognition does not mean a grant of an equal position. Philosophy and the human sciences were considered mainly for their propaedeutic value; they were mere preparatio evangelica (i.e., preparation for the Gospel's coming). "Greek philosophy," writes Clement of Alexandria, "purifies the soul and prepares it to receive the faith on which truth constructs knowledge," (Congar, 1968, p. 40). These thinkers still believed in the sufficiency of Scriptures; theology was still a sacra pagina but what is acknowledged is the role of the sciences in the elaboration of the Scripture's meaning. This position came to its eminence in Bonaventure's and Augustine's writings where faith served as life's all-pervading horizon. Intellectus, even as it is a necessary contemplative dimension can only be understood in reference to this faith and never separate from it - a paradigm expressed in the now famous axioms which Augustine originally expressed in his sermons, crede ut intelligas; intellige ut credas (believe that you may understand; understand that you may believe). Such is the theological culture that saturates up to the whole of Medieval Christendom: that all arts and sciences 'belong to Christ' and should be made to 'serve its true Master'. Consequently, theology thus becomes the queen "who was served and chaperoned by the arts and sciences, her servants," (Congar, 1968, p. 54)thus, the well-known 'handmaid' formula (ancilla theologiae) which almost amounts to a reduction of the arts and philosophy to theology (Benson, 2009).

\section{Philosophical Structuration of the Faith}

Such a subservient position arts and philosophy occupy vis-à-vis theology in the medieval times was far from being monolithic. The introduction of Aristotle's writings into the medieval arena radically changed the dominant Neo-platonic theological landscape. Though Aristotle's work on grammar and logic were utilized earlier on by the dialectical theologians (Alcuin, Abelard, Peter Lombard), it was Thomas Aquinas who provided an eminent synthesis of Aristotelianism and Christianity. While the dialecticians (who were familiar with the then pervasive work of Aristotle on logic) brought theology 
under the regime of grammar and dialectics, St. Thomas delivered theology to the regime of metaphysics (thanks to the eventful translation of the Aristotelian works on psychology, ethics and metaphysics). Terms like 'essence and existence', 'matter and form', 'act and potency', 'virtues and habits', easily characterize the theological landscape up to the recent past. Aristotle then provided a scientific structure with which to think the faith in new contexts. Theologia has thus become a scientia. But what value has philosophical science in St. Thomas' theology? Some theologians think that Aquinas has 'evacuated' philosophy in favor of theology (Milbank \& Pickstock, 2001, pp. 19-59). Most commentators, however, think that the Angelic Doctor gave philosophy its due autonomy. Unlike Augustine who considers human reason as purely subservient to the truths of faith, Aquinas believes that the human sciences explicate a truth about reality quite independent of revelation. Thus, in Aquinas' work, while theology is sometimes made to critique the conclusions of philosophy, his scientific framework is also made to revise untenable theological assertions. For Thomas, as for Albert the Great, his teacher, since things around us are endowed with intelligible consistency, the sciences based as they are on human ratio can be trusted. Philosophy is thus granted autonomy since its methods and its object - on its own - brings us to the truth of reality. Thus, the 'handmaid of theology' discourse which is also present in St. Thomas, (Aquinas, 2013) acquired quite a different sense from its original Augustinian context, for in order "to assure the services of her slave, theology begins by freeing her," (Congar, 1968, p. 107).

\section{The Hegemony of Scholastic Reason}

In the wake of Aquinas, the Scholastic mind developed from the $14^{\text {th }}-18^{\text {th }}$ centuries as it encountered new contexts: The Renaissance, the humanist movement, the Reformation and Counter-Reformation. The dialogue between ratio and sacra doctrina shifted to new emphasis. From being a commentary on the Scriptures and a disputation on the so-called 'truths of faith' via philosophical reason, theology is now co-opted by dialectics more concerned with methodic logic than with the truth of revelation. The 'quaestio' - a child of dialectics - started by Abelard and Peter Lombard consequently brought to perfection by Thomas Aquinas - was a significant step in theological method as it tries to ferret out the truth of the theological datum by the construction of aporias, i.e., two contradictory positions both supported by arguments. However, in the hands of Cajetan, Bañez, John of Saint-Thomas, to name the most prominent ones, the 'quaestio' has taken a life of its own, this time alienated from the original Scriptural question and faith context. The texts of the Scriptures and the writing of the Fathers were then neglected in favor of the works of Aristotle and the Scholastics. Theology became highly speculative and metaphysical grounded as it is in the now prevalent "Christian philosophy" which later earned the name 'philosophia perennis'. The role of faith then became a mere "preliminary, necessary to furnish the starting point, but truly borderline and extrinsic, while the real theological work is done by the simple application of metaphysics to this datum held as true," (Congar, 1968, p. 162). In an act of rebellion to the hegemony of logic, theology began to branch out into new specializations: mystical and ascetic theologies distinguished themselves from scholastic theology, moral theology and apologetics from dogmatic theology (in order to be a theological resource in pastoral contexts). Other theological disciplines followed. However, such acts of transgression were at best ambivalent since, caused by the exigencies of the times (i.e., Counter-Reformation program), the method they employed were themselves co-opted by the same neo-scholastic reason. By the end of $18^{\text {th }}$ century, all these new disciplines already their place in the so-called theological 'manuals' whose method was easily 
structured into five parts: (1) thesis; (2) status quaestionis (exposition of opinions on the subject); (3) positive proofs from authority and from theological reasoning; (4) solutions of the difficulties; and, (5) corollaries and application to Christian life and piety. Theology has traveled a long way - from reflection on the Scriptures, to a dialectical engagement aimed at theological construction, to a pedagogical program intended at explanation and apologetic demonstration.

\section{Theological Dialogue-Partners}

Due to the Counter-Reformation concerns of the post-Tridentine Church, Catholic theology found itself in a reactionary mode, almost oblivious to the cultural ferment of the world around it. It has remained metaphysical, scholastic, ahistorical and dogmatic - true of its name of being a theologia perennis. It was Protestant theology that, at the onset of the $19^{\text {th }}$ century, first attempted to dialogue with the new philosophical developments. Even as Thomas Aquinas' theology respected the autonomy of its philosophical 'other' (i.e., it freed its 'slave'), it still considers it as a handmaid just the same - a slip quite revelatory of its own location.

Contemporary theologies, however, developed from a different footing. It sought the human sciences to be its equal dialogue-partner in understanding the world where God is said to reveal Himself/Herself. Schleiermacher and Barth, even as they found themselves in opposite theological divides, are one in seeking the philosophical worldviews of their epoch to elaborate their theological construction. Schleiermacher was beholden to Kant; Karl Barth to Hegel. Rudolph Bultmann, Paul Tillich and John Macquarrie was in dialogue with existentialist thought; Karl Rahner and Bernard Lonergan, with neo-Kantianism and Martin Heidegger. John Cobb, David Tracy and Schubert Ogden engaged with process philosophy while Edward Schillebeeckx, Jürgen Moltmann and Johann Baptist Metz with critical social theory.

In recent years, theology engaged other sciences (sociology, anthropology, psychology, economics, biology, cultural studies, etc.) in fruitful dialogues: liberation theologians with Marxism and dependency theory; feminist and postmodern theologies with philosophies of deconstruction; African theologians with cultural theories and Asian theologians with philosophies from ancient religions. Underlying all these engagements is the belief that if theology is "faith seeking understanding", such 'understanding' cannot be a monopoly of the revealed word; it can also be discerned in the frameworks of contemporary sciences. Or, better still, the Word itself can only be revealed in the power and fragility of human reason.

\section{Interdisciplinary Theologizing in Asia: Method, Models and Issues}

How is interdisciplinarity appropriated in the Asian theological context? What are its dominant methodological principles? What are some of its existing forms?

\section{Interdisciplinary Theologizing in Asia: Methodological Principles}

First, the culture of dialogue as a constant in the traditions, philosophies, literatures and cultures in Asia can never be exaggerated (Black \& Patton, 2015). Asian cultures and religions can be described as dialogical because of a basic realization that no one view, no one culture, no one religion can totally comprehend complex Reality. The recognition of the limits of our vision necessitates disputation and conversation. The popular fable of the Blind Men and the Elephant common to all ancient religions of Asia (Hinduism, Jainism, Buddhism, Sufism) is quite known. The dialogic culture characterized by 
toleration and heterodoxy was encouraged by Ashoka, the Buddhist emperor of India (ca. ${ }^{\text {rd }}$ century $\mathrm{BCE}$ ), as he also "laid down what was perhaps were the oldest rules for conducting debates and disputations, with the opponents being duly honored in every say on all occasions," (Sen, 2005, pp. 12 13). From the Confucian tradition, the same challenge toward dialogue is found. The controversial book of Anthony de Mello, The Song of the Bird relates this narrative of Confucius, the Sage.

$\mathrm{Pu}$ Shang once said to Confucius, "What kind of a sage are you that you can say that Yen Hui excels you in straightforwardness? That in clarifying things Tuan-mu Tz'u is superior to you? That Chung Yu is more courageous than you? And that Chuan-sun Shih is more dignified than you?" In his eagerness to get a reply Pu Shang moved to the edge of the mat and nearly fell off it. "If these things are true," he said, "then why are these four men your disciples?"

Confucius replied, "Stay right where you are and I shall tell you. Yen Hui knows how to be straightforward but he does not know how to be flexible. Tuan-mu Tz'u knows how to clarify things, but he does not know how to give a simple Yes or No answer. Chung Yu knows how to be courageous, but he does not know how to be cautious. Chuan-su Shih knows how to be dignified but he does not know how to be unassuming. This is why these four men are glad to study under me (de Mello, 1981, pp. 160-161).

Second, true to the Asian spirit, Christianity, which also arrived in Asia during the early centuries of the Christian era, recognizes its own dialogical character (Wilfred, 2014, p. 130). Though eclipsed in the colonial times and counter-Reformation periods, contemporary Christian theology and reiterated the dialogic and pluralist character of its method. The FABC writes:

We have reflected on the rich and multiple resources of cultures, religions, movements, struggles and life-experiences of the Asian peoples as the context and locus of God's presence and action, and of the work of the Spirit... We begin to see with clarity that the great variety of situations and contexts calls for a pluralism of theological methods which is responsive, creative and promising for the Church in Asia in its mission of love and service of God's Kingdom (Office of Theological Concerns, 2002, p. 419).

In the face of conflict, poverty and diversity, Christian theology in Asia values integration, interrelatedness and wholeness, resistance to money and service to one's neighbor especially those "on the periphery and outside the Gate".

Third, this dialogical approach in theological method is premised on pluralism - the recognition and acceptance of variety of viewpoints, the diversity of perceiving subjects on the multidimensional complex reality. Such a pluralist perspective is not a characteristic of the colonial religious experience whose interpretation of reality has been hegemonically monologist from the West. But the experience of the Christianity has always been pluralistic from the beginning - with its different gospel accounts, theologies, liturgies and practices. This pluralism does not mean "relativism" as many feared. "All major Asian religions condemn such relativizing of reality, especially the relativizing of basic human values... Many Asian philosophies and theologies have shown the unity and harmony behind pluralism," (Office of Theological Concerns, 2002, p. 6).

Fourth, the search for unity in the midst of pluralism is premised on a specific epistemology. Even as argumentation, conversation and discussion are prevalent in the our cultures, Asian thinkers talk about advaita - an "overcoming of dialectics by means of introducing love at the ultimate level of reality," (Panikkar, 2010, p. 216). Between the "either-or" (dialectic) and "both-and" (relativistic), advaitic vision claims its value to some superior source of knowledge. "This third degree of 
knowledge," Pannikar argues, "comes into being not when we see or know, but when we are conscious that we are seen or known. It is neither sense knowledge nor rational knowledge, and yet it is inseparable from both. It is not irrationalism. It emerges when the dynamism of knowledge inverts its direction, as it were: we are aware that in touching we are touched, in knowing we are known. It is conscious that there is an illumination from above," (Panikkar, 2010, p. 92).

Fifth, the sense of harmony and equilibrium also characterizes Asian thinking in the spirit of yinyang mainly present in Chinese cultures and philosophies. This can provide as guide to dialogue and negotiation with others. To pursue harmony according to the Book of Changes is to pursue "moderation, fitting, balance, and harmony", one which is "beneficial to all things... to all four seasons, all things and the long-term stability of the state. Harmony is a controlling force, guiding all things to grow and change. Harmony is a state, deciding the balance among people, beings, and nature," (Zhang \& Constantinovits, 2016).

In Christian theology, harmony and equilibrium is confronted with prophecy and transformation, the serenity of the lotus meets the defiance of the cross (FABC-Theological Advisory Council, 1996). Aloysius Pieris argues for a twofold ascesis: first, an interior liberation dear to the Buddhists in the image of the Buddha deeply seated in contemplation under the tree of gnosis; second, struggle for human transformation symbolized by Jesus defiance in the cross, the tree of agape. "This double ascesis," Pieris continues, "is the nucleus around which an Asian theology of liberation evolves into a Christology that does not compete with Buddhology but complements it by acknowledging the one path of liberation on which Christians join Buddhists in their gnostic detachment (or the practice of 'voluntary poverty') and Buddhists join the Christian agapeic involvement in the struggle against 'forced poverty' as it truly happens today in the basic human communities in Asia," (Pieris, 1988, pp. 134-135).

\section{Interdisciplinary Theologizing in Asia: Models}

A landmark document of the FABC Office of Theological Concerns entitled Methodology. Asian Christian Theology: Doing Theology in Asia Today (FABC-Office of Theological Concerns, 2000) is a good place to start our reflection on theological interdisciplinarity. If we are to synthesize this long document (100 pages) from the perspective of our problematic, it will bear us two fields or spheres as dialogue partners of Christian theology in Asia: dialogue with Asian philosophies and religions; dialogue with social movements.

Theology in Dialogue with Asian Philosophies and Religions

A big part of Asian theological interdisciplinary approach (also read as interfaith or interreligious) is its dialogue with Asian philosophies and religions. This is an acknowledged unique contribution of the Asian churches to world theologies. Already in the first FABC meeting, we hear this: to preach the Gospel in Asia today, "involves a dialogue with the great religious traditions of our peoples... How can we not acknowledge that God has drawn our peoples through them?" (FABC, 1976). Subsequent FABC documents re-affirm this direction. Engagement with Hinduism, Buddhism, Islam, Confucianism, Taoism, and other great and ancient religions in Asia has filled the theological landscape since Christianity came to the Asian soil from the early years of Christianity. Their Scriptures and philosophical concepts become theological sources in the dialogical theological reflection and practical engagement. Literature on theological cross-fertilization - both official and 
popular - abound too many to mention here. A most recent analysis of this mutual influence is found in Felix Wilfred's edited work, The Oxford Handbook of Christianity in Asia (2014) (Wilfred, 2014, pp. 345-476). Christian theologians working in Asia rose to prominence in this field, to mention just a few - Jacques Dupuis, Michael Amaladoss, Sebastiano D'Ambra, M. Dhavony, Peter Phan, Aloysius Pieris, Kosuke Koyama, Choan-Sen Song, and many others.

Let me raise a question in this area: on which level is interreligious dialogue being done? Though there is a good theological production both in official texts and professional theology on this area, it seems that dialogues with other religions are stuck on that level. Or does it? I am teaching theology in Southern Philippines which is a predominantly Muslim area. After a class on interreligious dialogue, one Christian theology teacher commented: "Interreligious dialogue is only good in the classroom. In our neighborhood, what I feel is, at best, silent toleration; at worst, a sense hatred and prejudice." On the other hand, I have also temporarily immersed in mixed communities who live together in respectful peace and harmony. The Christians fasted with their Muslim neighbors during Ramadan; the Muslims joined the Catholics' Christmas party. In both levels, intentional interreligious dialogue does not happen. The so-called "Basic Human Communities" is good on paper. At least in the Philippines, they do not thrive quite well.

\section{Theology in Dialogue with Social Movements}

Heightened awareness on freedom and human dignity, justice and equality, ecology and gender is specifically present in social movements. Most often articulated in secular discourse, the social movements become a fruitful dialogue partner in Christian theological reflection in Asia. This dialogue bore fruit in the now famous theologies all over Asia - Minjung theology in Korea, Dalit theology in India, theologies of struggle, feminist theologies, ecological theology, migration theology, and many others. FABC has dedicated much of its reflections on this interface between Christian theology and peoples' movements. Asian Christian theologians dedicate their work on this field - to name just a few - Felix Wilfred, Samuel Rayan, Soosai Arokiasamy, Mary John Mananzan, Carlos Abesamis, and many others. In this spirit, FABC writes: “All movements for social change, events markings such a change, can be considered loci theologici (accepted theological resources) insofar as they embody the commitment of people to transform themselves and society. This commitment manifests the Spirit's presence," (FABC-Office of Theological Concerns, 2000, p. 33).

This direction challenges Christian reflection to get out of our intra-ecclesial concerns and engage in public theology - the concerns of the greater society. Felix Wilfred (2013, pp. 54-55) writes:

To speak of public theology is to speak of the future of Christianity in Asia in multicultural and multireligious societies in the larger horizon of the Kingdom of God. In these societies there is need to foster communion and build inclusive communities. Theology will help in this project by taking up for its praxis and reflection issues of common interest that affect everyone. This will help theology to be truly catholic in its original sense of comprising all, and it will not have the mark of being a sectarian enterprise limited to the faith-life of the Christian community. Asian public theology will tell what it means to live and understand the Kingdom of God in dialogue with the realities and experiences of this continent.

Let me raise one question on this level: are we engaged with social movements (their social theorists and practitioners) or with the grassroots themselves whom they claim to represent. Though an interdisciplinary engagement with another field (social movements) is helpful to check the biases 
theology has, the social scientists and organizers even as they claim to speak in behalf of the people (indigenous peoples, women, urban poor, dalits, etc.) could not really fully grasp the concerns of these same people. Theologians, social scientists and even community organizers are far removed from rough grounds where all these people live. We observe, theorize, discuss, write and, hopefully, act. But our constructs could not fully comprehend their concerns. A famous sociologist, Bourdieu and Wacquant (1992, pp. 69-70), says: "As soon as we observe (theorein) the social world, we introduce in our perception of it a bias due to the fact that, to study it, to describe it, to talk about it, we must retire from it more or less completely. This theocratists or intellectualist bias consists in forgetting to inscribe into the theory we build of the social world the fact that it is the product of a theoretical gaze, a 'contemplative eye'." In short, engagement with social movement practitioners is not enough. Theologians need to dialogue with the grassroots peoples themselves at the rough grounds.

Though this level of interdisciplinarity is in the heart and intention of the Asian bishops, it still needs to be seen how it works in concrete. For instance, FABC speaks of people-based hermeneutics: that Christ the teacher "speaks directly to the minds and hearts of people"; that they need to be empowered by giving them bibles or training them in bible sharing sessions in BECs. In a quite advance move, it writes: "Theologians will do well to accept the interpretations of Scriptures that emerge from the people, in the manner just described, as an important resource for doing theology in Asia," (FABC-Office of Theological Concerns, 2000, p. 42). But how this is to be done, we still need concrete structures in the grassroots level and a viable theological method in order to make this an effective and credible program.

\section{Conclusions: By Way of Questions}

First, we have realized through our cursory survey how "interdisciplinarity" is crucial to the Christian faith and theology but there is only a meager mention of it in both official church literature and seminary formation programs. For example, the recent Ratio has only one section where it mentioned of interdisciplinary seminars in the seminary formation: "Interdisciplinary seminars should be offered, to make common study more fruitful and to promote creative collaboration between teachers and seminarians at the scientific and intellectual level," (Congregation for the Clergy, 2016). A survey of seminary curriculum shows extensive exposure to both philosophical and theological sciences but not with other disciplines. Some seminaries are still stuck with scholasticism as main philosophical framework and there is hardly any mention of sociological, anthropology, psychological, much less, neuroscience, nanotechnology and other scientific fields. Yet these are the more influential scientific paradigms that run our present world. Consequently, we can ask: Are our theologies not stuck in the hegemony of scholastic reason reminiscent of the Middle Ages?

Second, at least among leading theologians in Asia, there is a recognized need to engage other disciplines. On the level of theological method, theology has entered into dialogue with other sciences at least in their writings. Multidisciplinary, in our categories above, is a recognized mode of doing theology. No decent Asian theologian refuses the mediation of other disciplines. However, it can also be observed that according to the category used above, such engagement is instrumentalist, that is, Christian theology merely "uses" the methods or findings of these sciences in order to explicate a theological concept. It has not yet reached a level interdisciplinarity where both disciplines respond to, critique and learn from the perspectives of the other. A real exchange of equal dialogue partners is still a desired vision, not a reality. 
Third, we can also ask the question: Are other sciences ready for this dialogical exchange? From its place of prominence in medieval universities, theology does not occupy any place at all in the modern academe. If ever they do, they are transformed into departments of 'religious studies' or some neutral and acceptable equivalents. No wonder, even in interdisciplinary collaboration, theology is seldom called upon; it being benignly labeled as 'sectarian' (also read as 'non-objective', thus, also non-scientific). This partly explains why initiatives towards interdisciplinarity unilaterally come from theology. For their part, other sciences display a "when I need you, I will call you" attitude vis-à-vis theology and religion. This also explains why interdisciplinary theology only remains at the level of instrumentalist 'borrowing'.

Fourth, we have seen that theological interdisciplinarity in Asia has gone beyond dialogue with academic disciplines. The brothers, Leonardo and Clodovis Boff identifies three levels of theological production: professional/academic; pastoral and grassroots. Professional theology, at least in the pronouncements and writings of leading theologians, already dialogues with religious traditions and social movements. This is an advance vis-à-vis academic interdisciplinarity in Western theologies - a unique contribution of the Asian churches. However, there is an observed disconnect between the academic level and the pastoral level (e.g., seminary formation or parish level reflection); and between the pastoral level and the grassroots. While theologians reflect on necessity of dialogue, parish priests continue to pontificate from the perspective of a received traditional training and the people continue to practice their Christian faith, sometimes without talking with their neighbors whose religious convictions are different from them. Is interdisciplinarity merely academic?

Fifth, we have earlier discussed the notion of transdisciplinary - one that is transgressive in character. Klein (2004, pp. 512-526) identifies two types of interdisciplinarity - horizontal (one which crosses disciplinary boundaries) and vertical (one which runs across the world of experts, policy makers and practitioners to the world of ordinary people). Scientific discourse has always been condescending 'as if people do not know', thus, needing the popularized versions of our highly technical researches. But when disciplinary borders open themselves to be transgressed, when society is provided with avenues to communicate with science, science will never be the same. "Science has a time which is not that of practice," says Bourdieu (1990, p. 81). Scientific disciplines are challenged to lay bare the results of their researches not only to co-experts but also to the 'agora' and ordinary people. A reflexive Christian theology is only possible when it realizes through its encounter with the 'rough grounds' of people's lives that its discourse can never truly and fully comprehend ordinary peoples' anxieties and concerns. It is only those from the 'rough grounds' who can confirm the validity but also confront the hypocrisy of our theological constructs. But as we found out, such structure on encounter does not yet exist in the Church and in theology.

\section{References}

Aquinas, S. T. (2013). Summa Theologica, Volume 5 (Part III, Second Section \& Supplement). Cosimo, Inc.

Black, B., \& Patton, L. (2015). Dialogue in Early South Asian Religions: Hindu, Buddhist and Jain

Traditions. London and New York: Routledge.

Benson, Joshua C. 2009. Identifying the Literary Genre of the "De reductione artium ad theologiam":

Bonaventure's Inaugural Lecture at Paris. Franciscan Studies 69, 149-178.

Bourdieu, B., \& Wacquant. (1992). An Invitation to Reflexive Sociology. Chicago: University of 
Chicago Press.

Bourdieu, P. (1990). The Logic of Practice, trans. Richard Nice. Stanford, CA: Stanford University Press.

Brazal, Agnes M., Pilario, Daniel F. E. (2007). Disciplines, Interdisciplinary and Theology. Hapág A Journal of Interdisciplinary Theological Research 4(1), 5-25.

Congar, Y. M. (1968). A History of Theology, trans. And ed. Hunter Guthrie. Garden City, New York: Doubleday and Company.

Congregation for the Clergy. (2016). The Gift of the Priestly Vocation. Ratio Fundamentalis Institutionis Scaerdotalis.

http://www.clerus.va/content/dam/clerus/Ratio\%20Fundamentalis/The\%20Gift\%20of\%20the\% 20Priestly\%20Vocation.pdf

de Mello, A. (1981). The Song of the Bird. New York: Doubleday.

FABC. (1974). Evangelization in Modern Day Asia," (Statement and Recommendations of the First Plenary Assembly). Hong Kong: Office of the Secretary-General.

FABC-Office of Theological Concerns. (2000). Methodology: Asian Christian Theology. Hong Kong: Office of the Secretary-General.

FABC-Theological Advisory Council. (1996). Asian Christian Perspectives on Harmony. Hong Kong: Office of the Secretary-General.

Foucault, M. (1991). Discipline and Punish: The Birth of a Prison, trans. Alan Sheridan. Harmondworth: Penguin.

Foucault, M. (1998). A Preface to Transgression," in Michel Foucault, Aesthetics, Method and Epistemology, ed. James Faubion. New York: New York Pres.

Fuller, S., \& Collier, J. H. (2004). Philosophy, Rhetoric, and the End of Knowledge: A New Beginning for Science and Technology Studies. Mahwah, NJ: Erlbaum.

Gaudium et spes. (1965). Retrieved June 27, 2020, from http://www.vatican.va/archive/hist_councils/ii_vatican_council/documents/vatii_const_19651207_gaudium-et-spes_en.html

Heidegger, M. (1977). Science and Reflections, " in The Question Concerning Technology and Other Essays, trans. William Lovett. New York: Harper and Row.

Instruction on Certain Aspects of Theologies of Liberation. (1984). Retrieved June 27, 2020, http://www.vatican.va/roman_curia/congregations/cfaith/documents/rc_con_cfaith_doc_198408 0 6_theology-liberation_en.html

Klein, J. T. (1990). Interdisciplinarity: History, Theory and Practice. Detroit, MI: Wayne State University Press.

Klein, J. T. (2004). Prospects for Transdisciplinarity. Futures 36(4), 515-526.

Klein, Julie Thompson. (2017). Typologies of Interdisciplinarity: The Boundary Work of Definition, The Oxford Handbook of Interdisciplinarity, 2nd ed., ed. Robert Frodeman. Oxford: Oxford University Press.

Luhmann, N. (1977). The Differentiation of Society. Canadian Journal of Sociology/Cahiers canadiens de sociologie, 2(1), 29-53.

Milbank, J. (1990). Theology and Social Theory: Beyond Secular Reason. Oxford: Balckwell.

Milbank, J., \& Pickstock, C. (2001). Truth in Aquinas. London: Routledge.

Office of Theological Concerns, F. (2002). Methodology: Asian Christian Theology, For All the 
Peoples of Asia, V.3 ed. Franz-Josej Eilers. Manila: Claretian.

Panikkar, R. (2010). The Rhythm of Being. Maryknoll, NY: Orbis Books.

Pieris, A. (1988). Love Meets Wisdom: A Christian Experience of Buddhism. Maryknoll, NY: Orbis Books.

Sen, A. (2005). The Argumentative Indian. London: Penguin Books.

Simon, H. (1992). Living in Interdisciplinary Space, Eminent Economists: Their Life and Philosophies, ed. M. Szenberg. Cambridge: Cambridge University Press.

St. Vincent School of Theology. (n.d.). Sexual Violence Against Women: Interdisciplinary Theological Conversations. Manila: Adamson University.

Wilfred, Felix. (2014). The Oxford Handbook of Christianity in Asia. Oxford: Oxford University Press.

Wilfred, F. (2013). On the Future of Asian Theology: Public Theologizing, in idem. (Ed), Theology to go Public. Delhi: ISPCK.

Wilfred, F. (2014). The Oxford Handbook of Christianity in Asia. Oxford and New York: Oxford University Press.

Zhang, S., \& Constantinovits, M. (2016). A Study of Principled Negotiation Based on Chinese Harmony Thought. Broad Research in Accounting, Negotiation, and Distribution 7(1), 60-70. 